\title{
STUDI LITERATUR HUBUNGAN UMUR IBU DAN PARITAS DENGAN KEJADIAN PERSALINAN PREMATUR
}

\author{
Insani Aulia Qisti ${ }^{1}$, Naimah, SKM., M.Kes ${ }^{2}$, Asworoningrum Y., S.SiT., M.Keb ${ }^{3}$ \\ Politeknik Kesehatan Kemenkes Malang \\ Email korespondensi: insaniiauliaa@gmail.com
}

\begin{abstract}
Abstrak
Indonesia adalah negara pada urutan kelima dengan persalinan preterm tertinggi di dunia yaitu sebesar 675.700 . Persalinan preterm dapat dipengaruhi oleh umur ibu dan paritas. Penelitian ini bertujuan untuk mengetahui hubungan antara umur ibu dan paritas dengan kejadian persalinan prematur. Metode yang digunakan adalah literature review dengan jenis literature review yang digunakan adalah tradisional literature review. Artikel didapatkan dari 4 database yaitu Pubmed, Google Scholar, Cochrane, dan DOAJ. Kata kunci yang digunakan dalam pencarian literatur: "Umur Ibu", "Paritas", "Persalinan Prematur", "Maternal Age", "Parity", "Preterm Labor", "Premature Birth". Hasil penelitian menunjukkan dari 15 jurnal yang didapatkan, didapatkan hasil bahwa $(92,3 \%)$ mengatakan ada hubungan antara umur ibu dan persalinan prematur dan $(7,7 \%)$ mengatakan tidak ada hubungan antara umur ibu dan persalinan prematur, $(85,7 \%)$ mengatakan ada hubungan antara paritas dengan persalinan prematur dan $(14,3 \%)$ mengatakan tidak ada hubungan antara paritas dengan persalinan prematur. Terdapat hubungan antara umur ibu dan paritas dengan kejadian persalinan prematur sehingga diharapkan tenaga kesehatan mampu memberikan pendidikan kesehatan dan konseling perencanaan kehamilan, memberikan perawatan antenatal yang sesuai standar serta memberikan informasi dan akses kontrasepsi agar dapat mencegah terjadinya persalinan prematur.
\end{abstract}

Kata kunci: Umur Ibu, Paritas, Persalinan Prematur

\begin{abstract}
Indonesia is the fifth country with the highest preterm delivery in the world, which is 675,700. Preterm delivery can be influenced by maternal age and parity. This study aims to determine the relationship between maternal age and parity with the incidence of preterm labor. The method used is a literature review with the type of literature review used is a traditional literature review. Articles were obtained from 4 databases, namely Pubmed, Google Scholar, Cochrane, and DOAJ. Keywords used in the literature search: "Maternal Age", "Parity", "Premature Birth", "Maternal Age", "Parity", "Preterm Labor", "Premature Birth". The results showed that from 15 journals obtained, it was found that (92.3\%) said there was a relationship between maternal age and preterm delivery and (7.7\%) said there was no relationship between maternal age and preterm delivery, (85.7\%)) said there was a relationship between parity and preterm labor and (14.3\%) said there was no relationship between parity and preterm delivery. There is a relationship between maternal age and parity with the incidence of preterm labor so that it is expected that health workers will be able to provide health education and pregnancy planning counseling, provide standardized antenatal care and provide information and access to contraception in order to prevent premature labor.
\end{abstract}

Keywords: Maternal Age, Parity, Premature Labor, Preterm Birth

\section{Pendahuluan}

Persalinan preterm adalah persalinan pada saat usia kehamilan 20 minggu sampai kurang dari 37 minggu. Persalinan preterm berkaitan dengan berat lahir rendah dan berpotensi meningkatkan kematian perinatal yaitu sebesar 65\%-75\%. (Nugroho, 2010) Menurut WHO, setiap tahun sekitar 15 juta bayi lahir prematur atau merupakan lebih dari 1 dari 10 bayi lahir di seluruh dunia. Secara global pada tahun 2014, 10,6\% dari seluruh kelahiran hidup merupakan kelahiran prematur (WHO,

\footnotetext{
${ }^{1}$ Mahasiswa Politeknik Kesehatan Kemenkes Malang

${ }^{2}$ Dosen Politeknik Kesehatan Kemenkes Malang

${ }^{3}$ Dosen Politeknik Kesehatan Kemenkes Malang
} 
2018). Indonesia adalah negara pada urutan kelima dengan persalinan preterm tertinggi di dunia yaitu sebesar 675.700 atau 15,5 per 100 kelahiran hidup. (WHO, 2012)

$$
\text { Angka kematian bayi }
$$
merupakan salah satu indikator dalam menilai derajat kesehatan masyarakat. Menurut hasil Survei Demografi dan Kesehatan Indonesia (SDKI) tahun 2017, angka kematian bayi (AKB) di Indonesia sebesar 24 per 1000 kelahiran hidup. Dapat kita ketahui bahwa komplikasi dari persalinan preterm ini berdampak besar pada kondisi bayi yaitu kemungkinan terjadinya asfiksia maupun bayi berat lahir rendah (BBLR) yang mana hal tersebut merupakan beberapa hal yang dapat menyebabkan kematian bayi di Indonesia.

Beberapa faktor sosio demografi yang berhubungan dengan persalinan preterm antara lain yaitu umur ibu, ras etnik, status pernikahan dan kondisi sosio ekonomi. Sedangkan faktor maternal yang berhubungan dengan persalinan preterm adalah inkompetensi serviks dan riwayat reproduksi, dengan riwayat reproduksi antara lain riwayat persalinan preterm, riwayat abortus, riwayat ketuban pecah dini, interval kehamilan dan paritas. (Krisnadi et al., 2014) Menurut Manuaba (2012) salah satu penyebab persalinan preterm adalah umur ibu. Usia terbaik untuk melahirkan yaitu usia 20-35 tahun. (Manuaba et al., 2012) Menurut Krisnadi (2009), kehamilan pertama lebih sering terjadi persalinan preterm. (Krisnadi, 2014) Menurut Wiknjosastro (2007), ditinjau dari sudut kematian maternal, paritas yang paling aman adalah 2-3, karena ibu dengan paritas tinggi (4 atau lebih) termasuk dalam kehamilan beresiko tinggi karena adanya penurunan fungsi sistem reproduksi.

Berdasarkan hasil penelitian Novalia Widya Ningrum, dkk pada tahun 2016 pada 231 ibu, didapatkan hasil bahwa sebanyak 77 orang ibu mengalami persalinan preterm dan 154 orang ibu tidak mengalami persalinan preterm. Pada ibu dengan persalinan preterm, sebanyak 38 orang $(49,35 \%)$ termasuk dalam usia beresiko dan sebanyak 39 orang $(50,65 \%)$ termasuk dalam usia tidak beresiko. Pada usia yang beresiko yaitu usia yang lebih muda dan lebih tua memiliki kemungkinan risiko 2,515 kali lebih besar mengalami persalinan preterm dibandingkan dengan ibu dengan usia tidak beresiko yaitu 20-35 tahun. Didapatkan pula hasil bahwa 77 orang ibu yang mengalami persalinan preterm, sebanyak 41 orang $(53,25 \%)$ termasuk dalam kelompok paritas beresiko dan 36 orang $(46,75 \%)$ termasuk dalam kelompok paritas tidak beresiko. Kejadian persalinan preterm 2,940 kali lebih beresiko pada ibu dengan paritas beresiko (1 dan lebih dari 3) dibanding ibu dengan paritas tidak beresiko (2 dan 3). (Ningrum et al., 2017)

Beberapa hal yang dapat membantu mengurangi persalinan preterm adalah keluarga berencana dan peningkatan pemberdayaan perempuan, terutama pada remaja dan peningkatan kualitas perawat sebelum, antara, dan selama kehamilan. (WHO, 2012) Solusi yang dapat dilakukan oleh tenaga kesehatan khsuusnya seorang bidan yaitu melakukan persiapan dalam perencanaan kehamilan yang mana hal ini dapat membantu mencegah terjadinya persalinan preterm dengan adanya konseling mengenai jumlah anak dan umur 
yang baik dalam kehamilan. Adapun solusi yang dapat dilakukan apabila kehamilan yang terjadi beresiko dari segi umur maupun paritas maka dapat dilakukan konseling mengenai kecukupan kebutuhan nutrisi, pengelolaan stress dan pola istirahat.

Berdasarkan pemaparan masalah di atas, dapat dilihat bahwa angka persalinan preterm masih tinggi di Indonesia. Oleh karena itu, peneliti tertarik untuk melakukan literature review dengan topik "hubungan umur ibu dan paritas dengan kejadian persalinan prematur".

\section{Metode}

Studi ni menggunakan metode literature review. Jenis literature review yang digunakan adalah Traditional Literature Review. Artikel diperoleh dari databased Google Scholar, PubMed, Cochrane dan DOAJ yang dipublikasikan dari tahun 2016-2020. Kata kunci yang digunakan dalam pencarian artikel nasional adalah umur ibu, paritas dan persalinan premature sedangkan dalam pencarian artikel internasional adalah Maternal Age, Parity, Preterm Labor, Premature Birth.

Kriteria Inklusi :

1. Studi yang berfokus pada ibu bersalin

2. Studi yang membahas tentang umur ibu dan paritas

3. Studi yang membahas tentang kejadian persalinan prematur

4. Studi yang menggunakan desain penelitian yang digunakan yaitu cross sectional, case control, descriptive, studi kohort retrospektif

5. Jurnal penelitian terakreditasi SINTA Ristekbrin, Terindeks Scopus, ISI Thomson/Web of Science
6. Jurnal penelitian berbahasa Bahasa Indonesia atau Bahasa Inggris

\section{Hasil dan Pembahasan}

Dalam literature review terdapat 15 studi yang ditemukan terdapat 13 studi yang membahas tentang hubungan antara umur ibu dengan kejadian persalinan prematur dan terdapat 7 studi yang membahas tentang hubungan antara umur ibu dengan kejadian persalinan prematur.

\section{Hubungan Umur Ibu dengan Kejadian Persalinan Prematur}

Sebagian besar hasil studi menunjukkan bahwa usia muda dan usia lanjut merupakan usia yang berisiko karena sebagian besar lebih sering terjadi persalinan preterm pada usia tersebut. Hal ini sejalan dengan pendapat Prawirohardjo et al. (2010) bahwa umur terbaik wanita untuk hamil yaitu antara umur 20-35 tahun karena pada umur tersebut secara psikologi sudah dewasa dan organ-organ reproduksi sudah matang. (Prawirohardjo et al., 2010)

Berdasarkan penelitian Waldenstrom et al. (2017) menyatakan bahwa kelompok yang melahirkan sangat prematur memiliki tingkat stressor potensial yang lebih tinggi, dan dalam hal ini ibu muda cenderung lebih terpapar pada faktor-faktor yang tidak terukur yang terkait dengan kerentanan psikososial, stress dan kecemasan. (Waldenström et al., 2017) Selain itu dalam penelitian Sakinah et al. (2017) dan Wagura (2018) didapatkan hasil bahwa pada usia ibu yang terlalu muda yaitu $<20$ tahun ibu cenderung masih labil dalam mengontrol emosinya dan cenderung mengalami 
kecemasan dan stress. (Sakinah et al., 2017) (Wagura, 2018) Menurut pendapat peneliti, ibu muda cenderung memiliki kondisi psikologis yang belum matang dan kurang mampu mengontrol emosi sehingga lebih rentan mengalami stress dan kecemasan yang mana hal ini dapat meningkatkan sekresi prostaglandin sehingga akan memicu terjadinya persalinan preterm.

Berdasarkan hasil penelitian (Syarif et al., 2017), ibu muda umur < 20 tahun memiliki kompetisi untuk pemenuhan kebutuhan nutrisi dan pematangan fisik sehingga beresiko tinggi menimbulkan dampak yang buruk pada neonatal. Hasil penelitian (Ariana \& Wathan, 2020) pada usia ibu terlalu muda yaitu $<20$ tahun berkaitan dengan belum matangnya organ reproduksi secara sempurna. Selain itu pada penelitian (Eliza et al., 2017) dan (Meihartati, 2018) didapatkan hasil bahwa secara fisik alat reproduksi pada usia $<20$ tahun cenderung belum terbentuk sempurna, dimana kondisi rahim relatif masih kecil dan pertumbuhan tulang panggul belum cukup lebar sehingga resiko terjadi infeksi akan meningkat akibat belum sempurnanya peredaran darah menuju serviks.

Hal ini sejalan dengan pendapat Rochjati (2011) bahwa ibu yang hamil pertama pada usia < 20 tahun, keselamatan dan kesehatan janin dalam kandungan diragukan karena pertumbuhan rahim dan panggul ibu belum matang. (Rochjati, 2011) Mekanisme terjadinya peningkatan resiko kejadian persalinan preterm pada ibu usia muda yaitu peredaran darah menuju serviks dan uterus belum sempurna sehingga hal ini akan berdampak pada pemberian nutrisi pada janin yang cenderung berkurang. Selain itu, keadaan kurangnya peredaran darah pada saluran genital juga dapat meningkatkan resiko infeksi yang akan beresiko meningkatkan kejadian persalinan preterm.

Menurut pendapat peneliti, kondisi ibu dengan usia $<20$ tahun masih membutuhkan nutrisi untuk pertumbuhan dan perkembangan dirinya sendiri, apabila ibu hamil pada usia tersebut maka akan terjadi kompetisi nutrisi antara ibu dan janin sehingga pemberian nutrisi pada janin kurang maksimal dan akan berdampak pada perkembangan dan pertumbuhan yang buruk.

Berdasarkan hasil penelitian (Waldenström et al., 2017) didapatkan hasil bahwa usia ibu lanjut dapat berkontribusi pada fungsi organ-organ reproduksi yang menurun yang dapat mempengaruhi terjadinya kelahiran prematur. Pada kelahiran yang terindikasi, hubungan dengan usia ibu lanjut sebagian besar dimediasi oleh pre-eklamsia, dan kondisi ini berhubungan dengan gangguan vaskular dan penurunan aliran darah utero-plasenta.

Menurut pendapat peneliti, ibu hamil dengan usia lanjut memiliki resiko lebih tinggi terjadi pre-eklampsia. Hal ini dikarenakan dalam mengatasi ibu yang mengalami preeklampsia berat salah satu cara yang dapat dilakukan yaitu dengan melakukan persalinan sebelum waktunya untuk menyelamatkan ibu dan janin sehingga dalam hal ini cenderung akan terjadi persalinan preterm.

Berdasarkan hasil penelitian Ariana \& Wathan (2020) usia ibu >35 tahun dikaitkan dengan kesehatan yang berkurang, fungsi dan 
kualitas rahim yang menurun. (Ariana \& Wathan, 2020) Pada penelitian Syarif et al. (2017), kehamilan dengan usia ibu >30 tahun memiliki peningkatan risiko gangguan kehamilan dan kelainan kongenital. (Syarif et al., 2017) Selain itu, menurut Eliza et al. (2017), Hidalgo-Lopezosa et al. (2019) dan Fuchs et al. (2018) dalam penelitiannya usia >35 tahun risiko komplikasi kehamilan akan meningkat seperti plasenta previa, diabetes gestasional, maupun kejadian prosedur invasive (pembedahan). (Eliza et al., 2017)(HidalgoLopezosa et al., 2019)(Fuchs et al., 2018) Sesuai dengan pendapat Cunningham dalam Syarif et al. (2017) wanita berusia > 35 tahun memiliki peningkatan risiko terjadinya persalinan preterm, plasenta previa, hipertensi, solutio plasenta, dan janin mati karena fungsi alat reproduksinya cenderung berkurang.(Syarif et al., 2017)

Menurut pendapat peneliti, ibu hamil dengan usia lanjut cenderung memiliki peningkatan resiko dalam mengalami komplikasi pada kehamilan yang mana akan berdampak pada mortalitas dan morbiditas bayi yang akan dilahirkan. Adapun keadaan kesahatan yang menurun pada ibu dengan usia lanjut termasuk terjadinya diabetes yang dapat meningkatkan risiko persalinan preterm karena janin dengan ibu diabetes cenderung lebih cepat besar sehingga dibutuhkan persalinan dini.

Berdasarkan hasil penelitian (Subriani et al., 2019) dan (Rosyidah et al., 2019), usia ibu $<20$ tahun fungsi organ belum sempurna karena organ-organ reproduksinya cenderung belum matang, sedangkan pada ibu usia >35 tahun memiliki resiko komplikasi lebih tinggi dan fungsi organ-organ reproduksi cenderung kurang maksimal. Hal ini sejalan dengan pendapat (Wahyuni \& Rohani, 2017) bahwa secara fisik alat reproduki pada wanita usia $<20$ tahun belum terbentuk sempurna sehingga rahim relatif masih kecil serta pembentukan tulang panggul yang belum cukup lebar akan meningkatkan risiko komplikasi pada maternal selama kehamilan dan persalinan serta meningkatkan risiko persalinan preterm. Sedangkan pada wanita usia > 35 tahun mengalami peningkatan risiko terjadinya komplikasi kehamilan sehingga akan berdampak pada mortalitas dan mordibitas bayi yang akan dilahirkan.

Menurut pendapat peneliti, pada usia $<20$ tahun alat reproduksi masih dalam proses pertumbuhan sehingga fungsinya cenderung kurang maksimal sedangkan pada ibu dengan usia >35 tahun alat reproduksi cenderung melemah sehingga fungsinya kurang maksimal sehingga hal tersebut dapat meningkatkan resiko terjadinya persalinan preterm.

Sehingga dapat disimpulkan bahwa usia ibu yang terlalu muda dan terlalu tua berhubungan dengan kejadian persalinan preterm dimana ibu dengan usia $<20$ tahun cenderung belum siap dari segi fisik yang mana organ reproduksi cenderung belum matang dan segi psikis yang mana cenderung masih labil dam mengontrol emosi dan juga kurangnya perhatian dalam memenuhi kebutuhan nutrisi. Sedangkan pada ibu dengan usia $>35$ tahun fungsi dari organ reproduksi cenderung menurun dan akan lebih rentan terjadi komplikasi yang akan berdampak pada mordibitas dan mortalitas bayi yang dilahirkan. 
Pada penelitian (Kuslimawati et al., 2020) yang mana didapatkan hasil bahwa tidak ada hubungan antara umur ibu dengan kejadian persalinan preterm. Hal ini dapat disebabkan oleh pengaruh dari daerah lokasi penelitian yang berbeda, dimana keadaan lokasi penelitian berpengaruh terhadap karakteristik sosial dan budaya. Menurut pendapat peneliti, karakteristik sosial dan budaya dapat mempengaruhi kondisi ibu hamil, seperti pada daerah yang memiliki kondisi sosial yang bagus kemungkinan akan menciptakan kondisi psikologi ibu hamil cenderung lebih baik. Pada ibu dengan usia muda cenderung memiliki tingkat kecemasan dan stress yang lebih tinggi, apabila lingkungan memiliki keadaan sosial yang bagus dapat membantu meminimalisir kecemasan dan stress sehingga dapat membantu mencegah kejadian persalinan preterm. Pada ibu dengan usia tua kemungkinan ada faktorfaktor perancu lain yang tidak diteliti oleh peneliti.

\section{Hubungan Paritas dengan Kejadian Persalinan Prematur}

Hasil studi menunjukkan bahwa paritas 1 atau primipara dan grandemultipara cenderung lebih beresiko mengalami kejadian persalinan preterm. Hal ini sejalan dengan pendapat (Krisnadi et al., 2014) bahwa persalinan preterm lebih sering terjadi pada kehamilan pertama dan akan berkurang dengan meningkatnya jumlah paritas hingga paritas keempat.

Berdasarkan hasil penelitian Eliza et al. (2017) pada paritas 1 atau primigravida, ibu lebih beresiko mengalami preeklampsia dan eklampsia, sehingga hal ini dapat menyebabkan komplikasi yang akan berdampak pada morbiditas dan mortalitas ibu dan bayi yang akan dilahirkan. (Eliza et al., 2017) Menurut pendapat peneliti, preeklampsia-eklampsia cenderung berdampak pada kehamilan yang harus diterminasi yang mana hal ini meningkatkan risiko terjadinya persalinan preterm.

Berdasarkan hasil penelitian (Ningrum et al., 2017) pada kelahiran pertama, keempat dan seterusnya akan mengalami peningkatan resiko kesehatan ibu dan anak, pada kehamilan dan persalinan pertama resiko kesehatan meningkat karena belum pernah mengalami kehamilan sebelumnya sehingga jalan lahir baru akan dilalui oleh janin. Sebaliknya jika terlalu sering melahirkan, kehamilan yang berulang akan menyebabkan adanya jaringan parut uterus sehingga rahim akan menjadi lebih lemah.

Menurut pendapat peneliti, pada ibu yang terlalu sering melahirkan dapat mempengaruhi persediaan darah ke plasenta yang akan menjadi tidak adekuat karena timbulnya jaringan parut pada uterus, sehingga hal ini akan berdampak pada tidak cukupnya aliran darah ke plasenta sehingga penyaluran nutrisi ke janin akan terganggu dan dapat berakibat pada gangguan pertumbuhan janin.

Berdasarkan hasil penelitian Subriani et al. (2019) wanita yang pernah melahirkan lebih dari satu kali atau yang termasuk dalam paritas tinggi yaitu multipara dan grandemultipara, fungsi organ reproduksinya akan menurun sehingga lebih beresiko melahirkan preterm dan lebih beresiko terjadi perdarahan antepartum. (Subriani et al., 2019) Hal ini sesuai dengan pendapat Berliana \& Sulistiarini (2016) bahwa 
paritas tinggi erat kaitannya dengan peningkatan usia ibu melahirkan. (Berliana \& Sulistiarini, 2016) Menurut pendapat peneliti, wanita yang termasuk paritas tinggi cenderung akan mengalami terminasi kehamilan lebih awal karena adanya penurunan fungsi reproduksi dan resiko terjadinya perdarahan antepartum.

Berdasarkan hasil penelitian (Koullali et al., 2020) persalinan preterm disebabkan oleh paritas tinggi karena salah satu faktor yang mungkin berperan bisa jadi serviks yang rusak. Leher rahim (serviks) berperan penting dalam menjaga kehamilan. Menurut pendapat peneliti, kerusakan pada serviks, misalnya dengan dilatasi dan kuretase atau eksisi loop pada serviks, berkontribusi pada risiko kelahiran prematur spontan yang lebih tinggi dikarenakan kurang maksimalnya kemampuan serviks dalam mempertahankan janin didalam kavum uteri sampai kehamilan aterm. Risiko prosedur semacam itu lebih tinggi terjadi pada wanita dengan usia atau paritas yang lebih tinggi.

Berdasarkan hasil penelitian (Wagura, 2018) paritas tinggi cenderung beresiko mengalami kelahiran prematur karena adanya perubahan uterus seperti peregangan miometrium dari kehamilan sebelumnya. Beberapa ibu dengan paritas tinggi juga memiliki riwayat kebidanan yang buruk yang mungkin disebabkan oleh faktor yang tidak teridentifikasi yang mungkin menetap pada kehamilan berikutnya. Selain itu, berdasarkan hasil penelitian (Apriani \& Nurjannah, 2020), pada ibu dengan paritas tinggi, alat-alat reproduksi cenderung lemah karena belum siap menerima implantasi dengan baik. Hal ini sejalan dengan pendapat (Joeharno, 2016) bahwa paritas grandemultipara akan berdampak pada timbulnya berbagai masalah kesehatan baik bagi ibu maupun janin. Menurut pendapat peneliti, alat-alat reproduksi yang lemah belum siap menerima implantasi dengan baik. Hal ini disebabkan oleh penurunan fungsi fisiologis dan reproduksi secara umum, terutama pada keadaan penurunan fungsi endometrium dan korpus uteri dan adanya pengurangan vaskularisasi dan oksigenasi pada hasil konsepsi yang tidak optimal sehingga memicu persalinan preterm.

Sehingga dapat disimpulkan bahwa paritas pertama meningkatkan resiko persalinan preterm karena ibu belum pernah mengalami kehamilan sebelumnya sehingga jalan lahir baru akan coba dilalui oleh janin. Sedangkan pada paritas tinggi rahim menjadi lebih lemah karena berkurangnya fungsi reproduksi syang disebabkan oleh jaringan parut uterus akibat kehamilan berulang.

Pada penelitian (Sakinah et al., 2017) yang mana didapatkan hasil bahwa tidak ada hubungan antara paritas dengan kejadian persalinan preterm. Hal ini dapat disebabkan oleh faktor lain yang tidak diteliti oleh peneliti yang mungkin dapat mempengaruhi hasil, seperti jarak kehamilan, frekuensi pemeriksaan kehamilan, anemia, pendidikan ibu, pekerjaan ibu dan lain-lain. Menurut pendapat peneliti, pada ibu dengan paritas tinggi memiliki pengalaman dalam menjalani kehamilan sehingga cenderung lebih siap dan lebih baik dalam menjaga kehamilannya sampai masa persalinan cukup bulan. Sedangkan pada ibu primipara dapat disebabkan oleh faktur perancu 
lain yang mungkin berpengaruh dan tidak diteliti oleh peneliti.

\section{Kesimpulan}

Berdasarkan hasil pengkajian dan pembahasan studi literature dari 15 jurnal, dapat ditarik kesimpulan bahwa terdapat hubungan antara umur ibu dengan kejadian persalinan prematur. Ibu dengan umur $<20$ tahun cenderung belum siap dari segi fisik dan segi psikis, sedangkan pada ibu dengan umur $>35$ tahun fungsi dari organ reproduksi cenderung menurun dan akan lebih rentan terjadi komplikasi. Terdapat hubungan antara paritas dengan kejadian persalinan prematur. Pada paritas pertama resiko akan meningkat karena ibu belum pernah mengalami kehamilan sebelumnya, sedangkan pada paritas tinggi fungsi reproduksi akan mengalami penurunan.

\section{Daftar Pustaka}

Apriani, W., \& Nurjannah, D. (2020). Jurnal Sains Kesehatan Vol. 27 No. 1 April 2020. 27(1), 23-29. http://jurnal.stikestrimandirisakti.ac.id/in dex.php/jsk/article/view/109/pdf

Ariana, R., \& Wathan, F. M. (2020). Di Rumah Sakit Umum Yk Madira Palembang Characteristics Risk Factors of Premature Birth in Yk Madira Public Hospital, Palembang. 7(November), 315-326.

Berliana, S. M., \& Sulistiarini, D. (2016). FAKTOR-FAKTOR YANG MEMENGARUHI KELAHIRAN PREMATUR DI INDONESIA: ANALISIS DATA RISKESDAS 2013 Dwi Sulistiarini dan Sarni Maniar Berliana. Dan Lingkungan, 1(2), 109-115.

Eliza, E., Nuryani, D. D., \& Rosmiyati, R. (2017). Determinan Persalinan Prematur di RSUD Dr. Abdul Moeloek. Jurnal Kesehatan, $\quad 8(2), \quad 305$. https://doi.org/10.26630/jk.v8i2.491
Fuchs, F., Monet, B., Ducruet, T., Chaillet, N., \& Audibert, F. (2018). Effect of maternal age on the risk of preterm birth: A large cohort study. Plos One, 13(1), e0191002. https://doi.org/10.1371/journal.pone.0191 002.t003

Hidalgo-Lopezosa, P., Jiménez-Ruz, A., Carmona-Torres, J. M., Hidalgo-Maestre, M., Rodríguez-Borrego, M. A., \& LópezSoto, P. J. (2019). Sociodemographic factors associated with preterm birth and low birth weight: A cross-sectional study. Women and Birth, 32(6), e538-e543. https://doi.org/10.1016/j.wombi.2019.03. 014

Joeharno, I. (2016). Konsep Dasar Risiko Bahaya Kehamilan. Salemba Medika.

Koullali, B., Van Zijl, M. D., Kazemier, B. M., Oudijk, M. A., Mol, B. W. J., Pajkrt, E., \& Ravelli, A. C. J. (2020). The association between parity and spontaneous preterm birth: A population based study. $B M C$ Pregnancy and Childbirth, 20(1), 1-8. https://doi.org/10.1186/s12884-02002940-w

Krisnadi, S. R. (2014). Prematuritas.

Krisnadi, S. R., Effendi, J. S., \& Pribadi, A. (2014). Prematuritas. PT Refika Aditama.

Kuslimawati, D., Wathan, F. M., \& Anggraini, H. (2020). Analisis Faktor Sosiodemografi Kejadian Persalinan Preterm di RSUP Dr. Mohammad Hoesin Palembang Tahun 2019. Jurnal Ilmiah Universitas Batanghari Jambi, 20(3), 902. https://doi.org/10.33087/jiubj.v20i3.1048

Manuaba, I. A. C., Manuaba, I. B. G. F., \& Manuaba, I. B. G. (2012). Ilmu Kebidanan, Penyakit Kandungan, dan $K B$. Perkumpulan Obstetri dan Ginekologi Indonesia.

Meihartati, T. (2018). The Relations Between Early Age Pregnancy With Premature Childbirth Occurence ). 4(1), 1-7.

Ningrum, N. W., Nurhamidi, \& Yusti. (2017). Hubungan Umur, Paritas dan Kejadian Anemia dengan Kejdian Persalinan 
Prematur di RSUD Dr. H. Moch. Ansari Saleh Banjarmasin Tahun 2016. Dinamika Kesehatan, 8(1), 149-157.

Nugroho, T. (2010). Kasus Emergency Kebidanan untuk Kebidanan dan Keperawatan. Nuha Medika.

Prawirohardjo, S., Saifuddin, A. B., Rachimhadhi, T., \& Wiknojosastro, G. H. (2010). Ilmu Kebidanan Sarwono Prawirohardjo. PT Bina Pustaka.

Rochjati, P. (2011). Skrining Antenatal Pada Ibu Hamil Edisi 2. Pusat Penerbitan dan Percetakan UNAIR.

Rosyidah, H., Viantika Kusumasari, R., Nur Adkhana, D., \& Surya Global Yogyakarta, Stik. (2019). Hubungan Usia Ibu Hamil Dengan Kejadian Persalinan Prematur Di Rsud Panembahan Senopati Bantul Yogyakarta Relationship Between the Age of Pregnant Women and Premature Labor in Panembahan Senopati Regional Public Hospital, Bantul, Yogyakarta. Bmj, 6(1), 14-23.

Sakinah, B. I., Husada, D., \& Sulistiawati. (2017). Faktor Risiko Kelahiran Prematur di RSUD Dr . M . Soewandhi Surabaya pada Tahun 2017. J Indon Med Assoc, 344-348.

Subriani, S., T, D. H., \& A, Z. Y. (2019). Faktor Yang Berhubungan Dengan Kejadian Bayi Lahir Prematur di RSUD Syekh
Yusuf Gowa Tahun 2019. Jurnal Kesehatan Delima Pelamonia, 3(2), 103110. https://doi.org/10.37337/jkdp.v3i2.132

Syarif, A. B., Santoso, S., \& Widyasih, H. (2017). Usia Ibu dan Kejadian Persalinan Preterm. Jurnal Kesehatan Ibu Dan Anak, 11(2), 20-24. https://doi.org/10.29238/kia.v11i2.35

Wagura, P. M. (2018). evalence and Factors Associated With Preterm Birth AtPr. BMC Pregnancy and Childbirth, 18(107), 2-9.

Wahyuni, R., \& Rohani, S. (2017). FaktorFaktor yang Mempengaruhi Persalinan Preterm. Jurnal Aisyah: Jurnal Ilmu Kesehatan, 2(1), 61-68. https://doi.org/10.30604/jika.v2i1.33

Waldenström, U., Cnattingius, S., Vixner, L., \& Norman, M. (2017). Advanced maternal age increases the risk of very preterm birth, irrespective of parity: a populationbased register study. BJOG: An International Journal of Obstetrics and Gynaecology, 124(8), 1235-1244. https://doi.org/10.1111/1471-0528.14368

WHO. (2012). Born To Soon.

WHO. (2018). Preterm Birth. https://www.who.int/news-room/factsheets/detail/preterm-birth 